\title{
Education and Employment in European Urban Communities
}

\author{
Cristina Dima ${ }^{1}$, Petrică Sorin Angheluță ${ }^{1, *}$, Constantin Marius Profiroiu ${ }^{1}$, and Petruț \\ Cristian Vasilache ${ }^{1}$ \\ ${ }^{1}$ Bucharest University of Economic Studies, Bucharest, Romania
}

\begin{abstract}
.
Research background: In the context of globalization, education processes are of great importance for the development of urban communities. Identifying the needs of the labour market should be the goal of any organization that provides education and training.

Purpose of the article: Globalization leads to the emergence of new specializations and qualifications. In order to facilitate the acquisition of competencies and abilities specific to new qualifications and specializations, it is necessary to involve education and training providers.

Methods: The article analyses the evolution of the employment rate, respectively of the unemployment rate. Urban communities need to respond to new societal, economic and environmental challenges.

Findings \& Value added: One of the major problems of urban communities is the risk of poverty and social exclusion. Thus, for the Member States of the European Union, the article presents the comparative situation of people at risk of poverty and social exclusion. For the Member States of the European Union, the evolution of the participation rate in education and training programs is followed in this article. The article also presents an analysis of the level of education of the urban population. Due to urban concentrations, the launch of new products and services is much easier.
\end{abstract}

Keywords: European Union; education; training; employment

JEL Classification: $I 21 ; I 25 ; J 21$

\footnotetext{
*Corresponding author: sorin.angheluta@gmail.com
} 


\section{Introduction}

In the context of globalization, education processes are of great importance for the development of urban communities. Identifying the needs of the labour market should be the goal of any organization that provides education and training. The labour market is changing as a result of digitalization, automation, technological progress. Population mobility has also begun to increase due to the digitization process. These changes put pressure on education and training systems. Often, the skills required by the labour market differ from the skills that graduates present themselves with when they want to occupy a job. Thus, there is a need to invest in education [1]. Investments in research and innovation have also led to the emergence of new technologies.

At European level, recognizing the value of the potential of education and training systems contributes to the realization of the European area of education. One of the challenging tasks for any society is given by the creation and implementation of new models in the field of education [2]. Economic growth, by focusing on the development of digital skills, allows the creation of new jobs [3].

Demographic characteristics, as well as social and economic characteristics, influence the educational needs of pupils and students. Graduates' performance may increase based on a high quality of education received [4]. An increased ability to adapt to change is a consequence of acquiring and possessing appropriate social, civic as well as entrepreneurial competences. Changes in education at the level of members of a society reduce inequities and influence social issues [5]. An increase in the number of tertiary graduates contributes to increased productivity, but it is considered that, for educational investment, this measure should be based on long-term planning strategies.

Students' participation in debates about the life of a society is facilitated by approaching familiar or comfortable topics. Otherwise, this can be a difficult endeavor, and student involvement becomes a challenge [6]. Recommended learning methods for students include learning through discovery and reflection. One of the models that has changed in recent years is given by technology education. The evolution from an emphasis on skills to an emphasis on technology education has enabled the acquisition of higher-level thinking skills, which has involved decision-making, critical thinking or problem solving [7]. This demonstrates the decisive role that teachers play in the process of academic and social integration of students [8]. Thus, by applying different training methods, knowledge can be developed and improved much more easily [9]. For different learning environments we identify different training practices [10]. In order to develop appropriate work habits, for the development of their own careers, students need training and volunteering internships [11]. Also, the development of professional and personal skills allow the acquisition of skills and competencies of employment [12]. However, the approach to solving wellframed problems in the education process does not involve solving multidimensional, complex problems in the workplace [13].

Globalization leads to the emergence of new specializations and qualifications. In order to facilitate the acquisition of competencies and abilities specific to new qualifications and specializations, it is necessary to involve education and training providers. The chances of finding a job are greatly diminished when contact with the labour market is lost [14]. Improving the quality of education and training processes can lead to the creation of new opportunities for young people $[15,16]$. In educational contexts, collective learning, through cooperation between colleagues, is considered to lead to better academic results [17]. Achieving by the tertiary level graduates the best possible results in the workplace is also based on how they have learned to organize their time and resources [18]. Employment does not mean that the danger of poverty or social exclusion has disappeared. 
Unemployment and low wages lead to loss of protection against poverty. Education and training can help to remove marginalization and the risk of social and economic exclusion [19]. Education and training processes allow members of a community to identify answers to local problems [20]. In this way, education and vocational training also participate in efforts to improve the quality of life. Is considered that in urban communities, health conditions as well as infrastructure contribute to increasing the quality of education [21].

The challenges in the labour market are easier to overcome if the members of society are people with high competences. Technological progress has led to a decrease in the number of jobs that require a low level of training. This has led older generations of graduates to focus on updating competences or acquiring new competences. As the number of tertiary graduates increases, the labour market reacts by providing a higher number of jobs for higher education graduates [22]. Through university-type teaching, those competencies are transmitted that bring the world of education closer to the world of work [23]. At work, an employee has to perform increasingly complex tasks. For this reason, in order to prevent certain discrepancies, intervention measures are needed both in the labour market and in the field of education. The new skills requirements also call for measures to adapt education and training systems. In this sense, correct decisions can be made by knowing the labour force needs, respectively the labour market trends.

\section{Methods}

For the period 2010-2019, the article presents the evolution of the share of the European population in the 15-64 age group, depending on the educational attainment level and degree of urbanization. Also, the evolution of the unemployment rate for the period 20102019 is presented, for the population living in cities, respectively in towns and suburbs, as well as the comparative situation, for the population aged between 15 and 64 years.

For the period 2010-2019, the evolution of employment rates for people living in cities and towns and suburbs is analyzed. At the same time, for 2019, the comparative situation of employment rates by educational attainment level and degree of urbanization is presented, for people in the age group 15-64 years.

From the point of view of the field of education, as well as of the labour market, it is important to know the share of people exposed to the risk of poverty and social exclusion. The article presents the comparative situation of the share of people exposed to the risk of poverty and social exclusion, for 2010 and 2018, for cities and towns and suburbs.

\section{Results and Discussions}

At the level of the European Union, the evolution of the share of the population in the age group 15-64 years, depending on the educational attainment level and degree of urbanization, for the period 2010-2019, is shown in Figure 1. It was taken into account that cities are considered be more densely populated areas, and towns and suburbs are those areas that have an intermediate density.

It is observed that the highest share is for the population of towns and suburbs which has 3-4 levels of education (upper secondary and post-secondary non-tertiary education). For the period 2010-2019, the share of the population of levels 3-4 in towns and suburbs, together with the share of the population of education levels 5-8 (tertiary education) in cities, respectively towns and suburbs, had an increasing trend. Also, the share of the population of levels $0-2$ (less than primary, primary and lower secondary education) had a decreasing trend. 


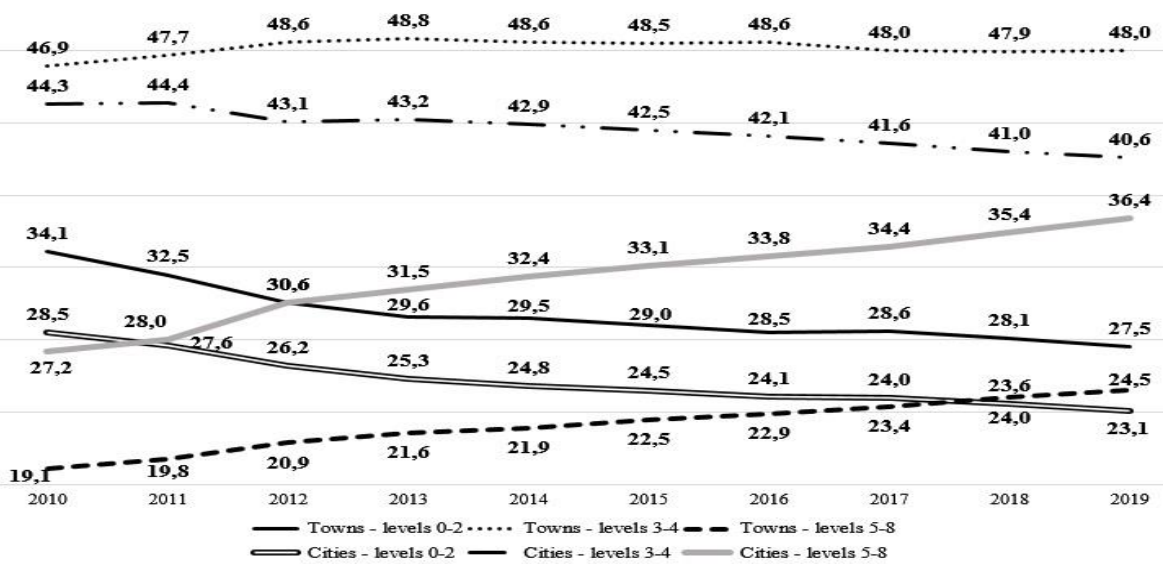

Fig. 1. The evolution of the share of the population in the age group 15-64 years, depending on the educational attainment level and degree of urbanization, for the period 2010-2019 (\%).

In 2019, the countries where the share of the population from cities, with education levels 5-8, was over $45 \%$ are: Luxembourg (70.4\%), Lithuania (50.6\%), Ireland (48.9\%), Sweden (47.3\%), Cyprus (46.9\%), Finland (45.6\%). Also, the countries where the share of the population in towns and suburbs, with education levels 5-8, was over $34 \%$ are: Ireland (39.1\%), Belgium (35.8\%), Cyprus (35.7\%), Finland (35.7\%), Sweden (34.6\%), Luxembourg (34.0\%).

From a regional point of view, the European regions where the share of population with education level 5-8 is the highest are: Warszawski stoleczny (Poland) (49.9\%), Sostines regionas (Lithuania) (49.4\%), Prov. Walloon Brabant (Belgium) (47.9\%), Basque Country (Spain) $(46.6 \%)$, Stockholm (Sweden) $(45.9 \%)$. This means that one in two people has a level of education between 5 and 8 . At the same time, the European regions with the lowest shares are in Romania: North-East (9.9\%), South-Muntenia (11.2\%), South-East $(12.2 \%)$. This means that in these regions, one in ten people between the ages of 15 and 64 has a higher education (levels 5-8).

Table 1. The comparative situation of the unemployment rate for the population aged 15 to 64 , living in cities, towns and suburbs, respectively for the entire population (\%).

\begin{tabular}{|c|c|c|c|c|c|c|c|c|c|}
\hline $\begin{array}{c}\text { Degree of } \\
\text { urbanisation }\end{array}$ & \multicolumn{3}{|c|}{ Total } & \multicolumn{3}{c|}{ Cities } & \multicolumn{3}{c|}{ Towns and suburbs } \\
\hline Gender & Total & Males & Females & Total & Males & Females & Total & Males & Females \\
\hline $\begin{array}{c}\text { European } \\
\text { Union }\end{array}$ & 6,8 & 6,5 & 7,2 & 7,7 & 7,7 & 7,8 & 6,6 & 6,2 & 7,1 \\
\hline Belgium & 5,4 & 5,8 & 5,0 & 9,0 & 9,7 & 8,2 & 3,7 & 4,0 & 3,5 \\
\hline Bulgaria & 4,3 & 4,6 & 3,9 & 2,5 & 2,5 & 2,4 & 4,1 & 4,7 & 3,4 \\
\hline Czechia & 2,1 & 1,8 & 2,4 & 2,0 & 1,8 & 2,3 & 2,3 & 2,0 & 2,6 \\
\hline Denmark & 5,1 & 4,9 & 5,4 & 6,2 & 6,2 & 6,3 & 4,9 & 4,5 & 5,3 \\
\hline Germany & 3,2 & 3,6 & 2,8 & 4,3 & 4,9 & 3,7 & 2,9 & 3,2 & 2,5 \\
\hline Estonia & 4,6 & 4,1 & 5,1 & 4,3 & 3,3 & 5,3 & 4,7 & 4,5 & 4,9 \\
\hline Ireland & 5,1 & 5,4 & 4,8 & 4,8 & 5,1 & 4,6 & 6,2 & 6,9 & 5,3 \\
\hline Greece & 17,5 & 14,1 & 21,7 & 18,4 & 15,2 & 22,2 & 18,1 & 14,5 & 22,6 \\
\hline Spain & 14,2 & 12,5 & 16,1 & 13,9 & 12,7 & 15,2 & 14,7 & 12,6 & 17,3 \\
\hline France & 8,5 & 8,6 & 8,4 & 9,9 & 10,5 & 9,3 & 8,7 & 8,5 & 8,9 \\
\hline Croatia & 6,7 & 6,2 & 7,3 & 6,1 & 6,8 & 5,4 & 7,2 & 6,0 & 8,6 \\
\hline Italy & 10,2 & 9,3 & 11,3 & 11,1 & 10,8 & 11,3 & 9,6 & 8,5 & 11,2 \\
\hline Cyprus & 7,3 & 6,5 & 8,1 & 7,0 & 7,0 & 7,0 & 7,8 & 6,0 & 9,7 \\
\hline Latvia & 6,5 & 7,3 & 5,7 & 6,2 & 6,8 & 5,6 & 4,9 & 5,8 & 4,1 \\
\hline Lithuania & 6,5 & 7,3 & 5,7 & 4,5 & 5,0 & 4,1 & 7,7 & 7,2 & 8,3 \\
\hline Luxembourg & 5,6 & 5,7 & 5,5 & 6,5 & 7,7 & 5,0 & 6,4 & 5,8 & 7,0 \\
\hline
\end{tabular}




\begin{tabular}{|c|c|c|c|c|c|c|c|c|c|}
\hline $\begin{array}{c}\text { Degree of } \\
\text { urbanisation }\end{array}$ & \multicolumn{4}{|c|}{ Total } & \multicolumn{3}{c|}{ Cities } & \multicolumn{3}{c|}{ Towns and suburbs } \\
\hline Gender & Total & Males & Females & Total & Males & Females & Total & Males & Females \\
\hline Hungary & 3,5 & 3,4 & 3,5 & 2,6 & 2,2 & 3,1 & 3,6 & 3,4 & 3,9 \\
\hline Malta & 3,5 & 3,3 & 3,7 & 4,8 & 4,5 & 5,1 & 2,3 & 2,2 & 2,3 \\
\hline Netherlands & 3,4 & 3,4 & 3,4 & 3,9 & 4,0 & 3,8 & 2,7 & 2,7 & 2,8 \\
\hline Austria & 4,6 & 4,7 & 4,4 & 8,1 & 8,9 & 7,3 & 3,9 & 3,8 & 4,0 \\
\hline Poland & 3,3 & 3,1 & 3,7 & 2,9 & 2,9 & 2,9 & 3,5 & 3,3 & 3,9 \\
\hline Portugal & 6,7 & 6,1 & 7,3 & 7,2 & 6,9 & 7,5 & 6,3 & 5,7 & 6,8 \\
\hline Romania & 4,0 & 4,4 & 3,5 & 2,7 & 3,1 & 2,2 & 4,6 & 4,8 & 4,3 \\
\hline Slovenia & 4,5 & 4,1 & 5,0 & 5,2 & 5,1 & 5,3 & 4,3 & 3,9 & 4,7 \\
\hline Slovakia & 5,8 & 5,7 & 6,0 & 3,5 & 3,7 & 3,3 & 6,0 & 5,5 & 6,6 \\
\hline Finland & 6,8 & 7,4 & 6,3 & 7,4 & 7,9 & 6,9 & 6,8 & 7,3 & 6,2 \\
\hline Sweden & 7,0 & 6,9 & 7,1 & 7,5 & 7,5 & 7,6 & 6,9 & 6,8 & 7,0 \\
\hline
\end{tabular}

From the existing data on the EUROSTAT website [24], at European level, the participation in education and training, in formal and non-formal context, increased for the period 2007-2016. Thus, for the population of cities the weights increased from $36.2 \%$ (in 2007 ) to $48 \%$ (in 2016), and for the population of towns and suburbs the weights increased from $33.9 \%$ (in 2007) at $44.4 \%$ (in 2016). In 2016, the countries with the highest values, both for the population living in cities and for the population living in towns and suburbs, are: Netherlands, Sweden and Austria.

For 2019, Table 1 presents the comparative situation of the unemployment rate for the population aged 15 to 64 , living in cities, towns and suburbs, respectively for the entire population.

It is noted that for the population aged 15 to 64 , the highest unemployment rates are in: Greece (17.5\%), Spain (14.2\%) and Italy (10.2\%). The situation is similar in the case of the analysis made for cities; Greece (18.4\%), Spain (13.9\%) and Italy (11.1\%), respectively for towns and suburbs: Greece (17.1\%), Spain (14.7\%) and Italy (9.6\%).

In these three countries, the situation remains the same whether it is males or females. It is observed that for females, in Greece, one person in 5 does not have a job, the shares of the unemployment rate being over $20 \%$.

However, there are several countries where the unemployment rate is low. Of the total population, the countries with the lowest shares are: Czechia (2.1\%), Germany (3.2\%), Poland (3.3\%), Netherlands (3.4\%), Hungary (3.5\%), Malta (3.5\%). For the population living in cities, the countries with low weights are: Czech Republic (2.0\%), Bulgaria $(2.5 \%)$, Hungary $(2.6 \%)$, Romania (2.7\%), Poland (2.9\%). For the population living in towns and suburbs, the countries with low weights are: Czech Republic (2.3\%), Malta $(2.3 \%)$, Netherlands $(2.7 \%)$, Germany $(2.9 \%)$, Poland (3.5\%).

Figure 2 shows the evolution of the unemployment rate for the period 2010-2019, for the population living in cities, respectively in towns and suburbs.

It is observed that in the period 2010-2011, the unemployment rate was constant, and in the period 2011-2013, the unemployment rate increased. For the period 2013-2019, in both situations (cities, respectively towns and suburbs), the trend of the unemployment rate was a decreasing one. Thus, in 2019, the values were lower than those recorded in 2010.

Regarding the situation by region, according to data published by EUROSTAT, in 2019, the regions with the lowest unemployment rates were in: Praha $(1.3 \%)$, Strední Cechy (1.3\%), Jihozápad (1.6\%), Severovýchod (1.7\%) and Jihovýchod (1.9\%), all from the Czech Republic, respectively Nyugat-Dunántúl (1.8\%) and Közép-Dunántúl (1.9\%), both from Hungary. 


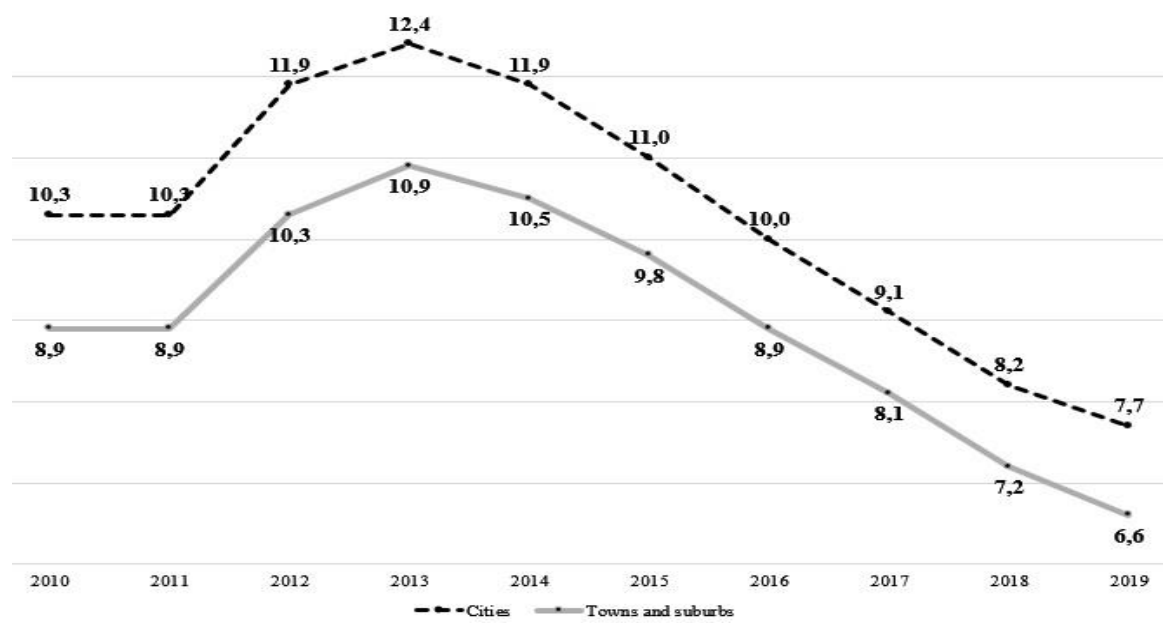

Fig. 2. The evolution of the unemployment rate for the period 2010-2019, for the population living in cities, respectively in towns and suburbs (\%).

By contrast, the highest unemployment rates were recorded in: Mayotte (France) (30.3\%), Ciudad Autónoma de Ceuta (26.0\%) and Ciudad Autónoma de Melilla (Spain) (27.1\%), respectively Dytiki Ellada (24.4\%) and Dytiki Makedonia (Greece) (24.8\%).

For 2019, Table 2 presents the comparative situation of employment rates by educational attainment level and degree of urbanization, for people in the age group 15 - 64 years.

Table 2. The comparative situation of employment rates by educational attainment level and degree of urbanization, for people in the age group 15 - 64 years (\%).

\begin{tabular}{|c|c|c|c|c|c|c|}
\hline Degree of urbanisation & \multicolumn{3}{|c|}{ Cities } & \multicolumn{3}{c|}{ Towns and suburbs } \\
\hline Educational attainment level & $\begin{array}{c}\text { Levels } \\
\mathbf{0 - 2}\end{array}$ & $\begin{array}{c}\text { Levels } \\
\mathbf{3 - 4}\end{array}$ & $\begin{array}{c}\text { Levels } \\
\mathbf{5 - 8}\end{array}$ & $\begin{array}{c}\text { Levels } \\
\mathbf{0 - 2}\end{array}$ & $\begin{array}{c}\text { Levels } \\
\mathbf{3 - 4}\end{array}$ & $\begin{array}{c}\text { Levels } \\
\mathbf{5 - 8}\end{array}$ \\
\hline European Union & 43,4 & 68,5 & 84,6 & 46,4 & 72,9 & 84,7 \\
\hline Belgium & 31,2 & 60,0 & 81,6 & 39,1 & 70,3 & 85,0 \\
\hline Bulgaria & 35,4 & 73,9 & 89,0 & 36,1 & 78,0 & 88,7 \\
\hline Czechia & 28,1 & 80,1 & 86,4 & 28,5 & 80,7 & 83,9 \\
\hline Denmark & 50,5 & 75,4 & 86,3 & 53,5 & 81,8 & 88,0 \\
\hline Germany & 46,6 & 76,9 & 88,0 & 51,0 & 82,0 & 89,4 \\
\hline Estonia & 40,5 & 80,5 & 87,5 & 39,8 & 77,0 & 85,2 \\
\hline Ireland & 36,0 & 69,5 & 86,2 & 32,1 & 68,9 & 84,1 \\
\hline Greece & 28,8 & 50,3 & 76,3 & 32,4 & 55,4 & 74,4 \\
\hline Spain & 50,8 & 60,3 & 80,5 & 53,0 & 62,0 & 80,1 \\
\hline France & 36,9 & 60,7 & 82,1 & 39,4 & 65,6 & 83,2 \\
\hline Croatia & 17,2 & 63,9 & 84,9 & 25,1 & 65,8 & 79,7 \\
\hline Italy & 40,8 & 63,2 & 80,6 & 45,0 & 65,8 & 78,3 \\
\hline Cyprus & 42,9 & 68,5 & 83,7 & 47,8 & 73,3 & 84,2 \\
\hline Latvia & 32,4 & 73,0 & 89,9 & 34,9 & 75,1 & 88,1 \\
\hline Lithuania & 18,4 & 73,1 & 91,9 & 26,6 & 71,5 & 88,6 \\
\hline Luxembourg & 37,1 & 63,0 & 86,5 & 46,1 & 65,4 & 84,2 \\
\hline Hungary & 33,5 & 72,9 & 86,2 & 36,2 & 75,2 & 84,4 \\
\hline Malta & 63,2 & 74,5 & 86,4 & 62,5 & 74,6 & 90,6 \\
\hline Netherlands & 57,4 & 77,4 & 87,7 & 65,5 & 82,9 & 90,4 \\
\hline Austria & 41,4 & 69,7 & 80,9 & 51,8 & 76,5 & 87,0 \\
\hline Poland & 21,9 & 67,4 & 89,1 & 21,4 & 67,7 & 87,4 \\
\hline Portugal & 57,6 & 72,4 & 86,8 & 63,8 & 74,8 & 84,8 \\
\hline & & & & & & \\
\hline
\end{tabular}




\begin{tabular}{|c|c|c|c|c|c|c|}
\hline Degree of urbanisation & \multicolumn{3}{|c|}{ Cities } & \multicolumn{3}{c|}{ Towns and suburbs } \\
\hline \multirow{2}{*}{ Educational attainment level } & Levels & Levels & Levels & Levels & Levels & Levels \\
& $\mathbf{0 - 2}$ & $\mathbf{3 - 4}$ & $\mathbf{5 - 8}$ & $\mathbf{0 - 2}$ & $\mathbf{3 - 4}$ & $\mathbf{5 - 8}$ \\
\hline Romania & 28,3 & 67,1 & 90,5 & 38,5 & 67,8 & 87,3 \\
\hline Slovenia & 29,0 & 69,2 & 89,3 & 34,4 & 73,6 & 88,7 \\
\hline Slovakia & 13,6 & 75,8 & 83,2 & 18,5 & 73,9 & 79,9 \\
\hline Finland & 37,7 & 71,4 & 86,2 & 38,2 & 74,7 & 86,1 \\
\hline Sweden & 44,2 & 78,8 & 87,5 & 45,5 & 83,6 & 89,8 \\
\hline
\end{tabular}

From the presented data it is observed that, both for the population living in cities and for the one in towns and suburbs, the employment rate for people with less than primary, primary and lower secondary education (levels $0-2$ ) is over $50 \%$ in the countries: Malta, Portugal, Netherlands, Spain, Denmark, Germany.

Also, for people with upper secondary and post-secondary non-tertiary education (levels $3-4)$, the employment rate is over $75 \%$ for the population living in cities in: Estonia, Czechia, Sweden, Netherlands, Germany, Slovakia, Denmark. The employment rate for people with upper secondary and post-secondary non-tertiary education (levels 3-4) is over $80 \%$ for the population living in towns and suburbs in: Sweden, Netherlands, Germany, Denmark, Czechia.

For people living in cities and having tertiary education (levels 5-8), the employment rate is over $88 \%$ in: Lithuania, Romania, Latvia, Slovenia, Poland, Bulgaria, Germany. At the same time, the employment rate is over $88 \%$ for the population living in towns and suburbs and has tertiary education (levels 5-8) in the countries: Malta, Netherlands, Sweden, Germany, Bulgaria, Slovenia, Lithuania, Latvia, Denmark.

Figure 3 shows the evolution of employment rates for people living in cities and towns and suburbs, for the period 2010-2019.

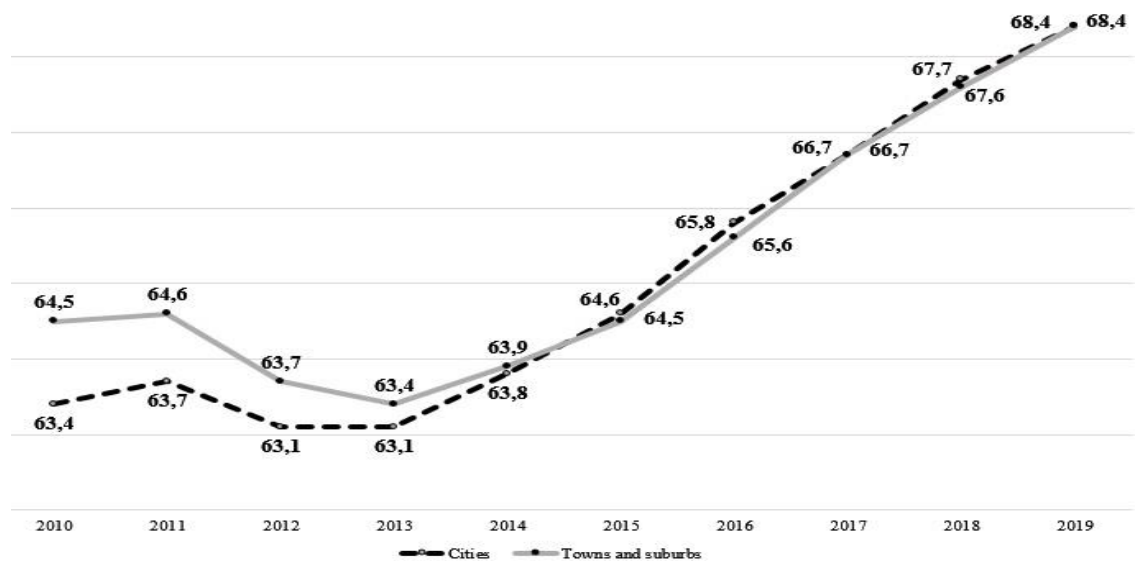

Fig. 3. The evolution of employment rates for people living in cities and towns and suburbs, for the period 2010-2019 (\%).

It is observed that if in the period 2011-2013 the trend was decreasing, for the period 2013-2019, the employment rates trend is an increasing one. Thus, in 2019, both for those living in cities and for those living in towns and suburbs, the employment rate is $68.4 \%$.

Knowing the share of people at risk of poverty and social exclusion is important both in terms of education and the labour market. Thus, Table 3 presents the comparative situation of the share of persons exposed to the risk of poverty and social exclusion, for 2010 and 2018 , for cities, respectively towns and suburbs. 
Table 3. The comparative situation of the share of persons exposed to the risk of poverty and social exclusion, for 2010 and 2018, for cities, respectively towns and suburbs (\%).

\begin{tabular}{|l|l|l|l|l|}
\hline \multirow{2}{*}{ Degree of urbanisation } & \multicolumn{3}{l|}{ Cities } & \multicolumn{2}{l|}{ Towns and suburbs } \\
\cline { 2 - 5 } & 2010 & 2018 & 2010 & 2018 \\
\hline European Union & 22,2 & 21,4 & 20,5 & 19,8 \\
\hline Belgium & 24,5 & 29,2 & 16,4 & 15,6 \\
\hline Bulgaria & 38,1 & 24,3 & 53,0 & 29,1 \\
\hline Czechia & 12,5 & 12,0 & 14,3 & 12,9 \\
\hline Denmark & 21,8 & 20,8 & 15,9 & 15,1 \\
\hline Germany & 20,8 & 22,4 & 17,1 & 16,1 \\
\hline Estonia & 18,2 & 22,1 & 25,9 & 20,4 \\
\hline Ireland & 24,3 & 17,6 & 27,8 & 25,8 \\
\hline Greece & 23,7 & 30,5 & 23,3 & 30,1 \\
\hline Spain & 22,5 & 23,2 & 28,3 & 26,9 \\
\hline France & 21,2 & 19,7 & 16,7 & 19,2 \\
\hline Croatia & 23,9 & 18,3 & 24,6 & 23,5 \\
\hline Italy & 24,4 & 29,2 & 24,8 & 26,1 \\
\hline Cyprus & 24,3 & 20,4 & 20,9 & 28,3 \\
\hline Latvia & 35,4 & 24,2 & 41,6 & 30,2 \\
\hline Lithuania & 30,0 & 19,4 & $:$ & 28,7 \\
\hline Luxembourg & 21,7 & 24,2 & 12,2 & 25,1 \\
\hline Hungary & 22,1 & 14,2 & 30,4 & 18,9 \\
\hline Malta & 21,1 & 19,5 & 22,8 & 15,0 \\
\hline Netherlands & 15,8 & 19,8 & 14,0 & 12,4 \\
\hline Austria & 25,3 & 25,5 & 14,9 & 13,5 \\
\hline Poland & 21,1 & 13,4 & 26,8 & 16,0 \\
\hline Portugal & 22,4 & 20,0 & 25,9 & 19,8 \\
\hline Romania & 29,1 & 18,6 & 39,6 & 24,9 \\
\hline Slovenia & 16,8 & 16,3 & 17,3 & 15,6 \\
\hline Slovakia & 15,9 & 10,4 & 19,1 & 16,4 \\
\hline Finland & 16,0 & 16,6 & 16,0 & 16,2 \\
\hline Sweden & 19,5 & 16,9 & 15,5 & 17,0 \\
\hline & & & & \\
\hline & 3,9 & \\
\hline
\end{tabular}

From the data presented in Table 3, it is observed that for the population living in cities, in 2018 , the countries with the highest values for people at risk of poverty or social exclusion are: Greece (30.5\%), Belgium (29.2\%), Italy (29.2\%), Austria (25.5\%).

Also, for towns and suburbs, the countries with the highest values are: Latvia $(30.2 \%)$, Greece (30.1\%), Bulgaria (29.1\%), Lithuania (28.7\%), Cyprus (28.3\%), Spain $(26.9 \%)$, Italy (26.1\%), Ireland (25.8\%).

However, compared to 2010, in 2018, for some countries, the share of people at risk of poverty or social exclusion decreased. Thus, for the population of cities we have: Bulgaria $(-13.8 \%)$, Latvia (-11.2\%), Lithuania (-10.6\%), Romania (-10.5\%). For the population of towns and suburbs we have: Bulgaria $(-23.9 \%)$, Romania $(-14.7 \%)$, Hungary $(-11.5 \%)$, Latvia (-11.4\%), Poland (-10.8) \%).

\section{Conclusions}

Within the European Urban Agenda, local communities have an important role to play in employment and education. Cities contribute to the economic and social development of a region. The predominant manifestation of innovation and creativity in urban areas allows the realization of partnerships, which help to identify the necessary solutions for a sustainable local urban development. 
The analysis of the evolution of the share of the population in the age group 15-64, depending on the educational attainment level and degree of urbanization, for the period 2010-2019, showed that the highest share is for the population in towns and suburbs, with education levels 3-4. For the period 2010-2019, the share of the population with education levels 3-4 in towns and suburbs, together with the share of the population of education levels 5-8 in cities and towns and suburbs, respectively, had an increasing trend. Also, the share of the population with education levels $0-2$ had a decreasing trend. It was found that, at European level, in the period 2007-2016, participation in education and training, in a formal and non-formal context, increased. For the period 2013-2019, in both situations (cities, respectively towns and suburbs), the trend of the unemployment rate was a decreasing one. Thus, in 2019, the values were lower than those recorded in 2010. At the same time, both for people living in cities and for people living in towns and suburbs, the period 2013-2019, the trend of employment rates was an ascending one. Sustainable urban growth in the European Union is based on job creation and economic recovery [25]. Investments in education and training also make a special contribution to economic growth. Through the contribution of education and training, the acquisition of new skills and abilities increases employment capacity. Demographic changes and environment changes, also, lead to changes in the labour market.

\section{References}

1. European Commission (2018). Building a stronger Europe: the role of youth, education and culture policies.

2. Odell, M.R., Kennedy, T.J., Stocks, E. (2019). The Impact of PBL as a STEM School Reform Model. Interdisciplinary Journal of Problem-Based Learning, 13(2).

3. European Commission (2019). Reflection Paper - Towards a Sustainable Europe by 2030.

4. Costache, G., Marinas, C.V., Igret, R., Burlacu, S. (2015). Internship in the HR department-organizational and individual perspectives. In I. Popa, C. Dobrin, CN Ciocoiu (Eds.), Proceedings of the International Management Conference (9(1), pp. 359-370). Bucharest: Editura ASE.

5. Organization for Economic Cooperation and Development (2019). Trends Shaping Education 2019. OECD Publishing, Paris.

6. Marty, L., Venturini, P., Almqvist, J., (2018). Teaching traditions in science education in Switzerland, Sweden and France: A comparative analysis of three curricula. European Educational Research Journal, 17(1), 51-70.

7. Rupnik, D., Avsec, S. (2020). Effects of a transdisciplinary educational approach on students' technological literacy. Journal of Baltic Science Education, 19(1), 121-141.

8. Androniceanu, A., Burlacu, S. (2017). Integration of educational technologies in universities and students' perception thereof. In The International Scientific Conference eLearning and Software for Education (2, p. 26). „Carol I” National Defence University.

9. Håkansson, M., Östman, L., Van Poeck, K. (2018). The political tendency in environmental and sustainability education. European Educational Research Journal, 17(1), 91-111.

10. Asunda, P.A., Quintana, J. (2018). Positioning the T and E in STEM: A STL Analytical Content Review of Engineering and Technology Education Research. Journal of Technology Education, 30(1), 2-29. 
11. Pereira González, M., Martís Flórez, R., Pascual Díez, J. (2019). Evaluation of career guidance and career education needs in six University Degrees on Education. Bases for the development of the Tutorial Action Plan. Educación XX1, 22(2), 309-334.

12. Rădulescu, C.V., Bodislav, D.A., Burlacu, S. (2018). Demographic explosion and it governance in public institutions. Managerial Challenges of the Contemporary Society. Proceedings, 11(1), 18.

13. Danaher, M., Schoepp, K. (2020). Effective assessment of workplace problem-solving in higher education. Journal of Information Technology Education: Research, 19, 1-16.

14. European Centre for the Development of Vocational Training (Cedefop) (2018). From long-term unemployment to a matching job: the role of vocational training in sustainable return to work. Luxembourg: Publications Office.

15. European Commission (2016). Communication from the Commission to the European Parliament, the Council, the European Economic and Social Committee and the Committee of the Regions 'Next steps for a sustainable European future European action for sustainability'

16. Bran, F., Burlacu, S., Alpopi, C. (2018). Urban Transport of Passengers in Large Urban Agglomerations and Sustainable Development. Experience of Bucharest Municipality in Romania. European Journal of Sustainable Development, 7(3), 265-273.

17. Pulgar, J., Candia, C., Leonardi, P.M. (2020). Social networks and academic performance in physics: Undergraduate cooperation enhances ill-structured problem elaboration and inhibits well-structured problem solving. Physical Review Physics Education Research, 16, 010137.

18. Formanek, M., Buxner, S., Impey, C., Wenger, M. (2019). Relationship between learners' motivation and course engagement in an astronomy massive open online course. Physical Review Physics Education Research, 15, 020140.

19. European Court of Auditors (2017). Special report No 5/2017: Youth unemployment have EU policies made a difference?

20. Burlacu, S., Gavrilă, A., Popescu, I.M., Gombos, S.P., Vasilache, P.C. (2020). Theories and Models of Functional Zoning in Urban Space. Revista de Management Comparat International, 21(1), 44-53.

21. Bernardo, J.S., Almeida, F.M. de, Nascimento, A.C.C. (2020). Qualidade geral da educação municipal e as influências dos gastos públicos. Arquivos Analíticos de Políticas Educativas, 28(23).

22. Pires de Carvalho Oliveira Silva, C.S., Freire-Seoane, M.J., López-Bermúdez, B. (2019). Un análisis de la formación terciaria entre los trabajadores dependientes e independientes: El caso de Portugal. Archivos Analíticos de Políticas Educativas, 27(46).

23. González-Morales, O., Santana-Vega, L.E. (2020). Diseño de un plan de acción para la empleabilidad de los universitarios. Archivos Analíticos de Políticas Educativas, 28(88).

24. EUROSTAT (2020). Retrieved from: https://ec.europa.eu/eurostat/data/statistics-a$\mathrm{z} / \mathrm{abc}$

25. European Council (2015). 2015 Joint Report of the Council and the Commission on the implementation of the strategic framework for European cooperation in education and training (ET 2020) - New priorities for European cooperation in education and training. 